\title{
Outward bound: women translators and scientific travel writing, 1780-1800
}

Article

Accepted Version

Martin, A. E. (2016) Outward bound: women translators and scientific travel writing, 1780-1800. Annals of Science, 73 (2). pp. 157-169. ISSN 0003-3790 doi:

https://doi.org/10.1080/00033790.2014.904633 Available at https://centaur.reading.ac.uk/36599/

It is advisable to refer to the publisher's version if you intend to cite from the work. See Guidance on citing.

To link to this article DOI: http://dx.doi.org/10.1080/00033790.2014.904633

Publisher: Taylor and Francis

All outputs in CentAUR are protected by Intellectual Property Rights law, including copyright law. Copyright and IPR is retained by the creators or other copyright holders. Terms and conditions for use of this material are defined in the End User Agreement.

\section{www.reading.ac.uk/centaur}

\section{CentAUR}

Central Archive at the University of Reading

Reading's research outputs online 


\title{
Outward Bound: Women Translators and Scientific Travel Writing, 1780-1800
}

\author{
ALISON. E. MARTIN \\ University of Reading (UK), Martin-Luther-Universität Halle-Wittenberg (Germany) \\ Email: a.e.martin@reading.ac.uk
}

\begin{abstract}
As the Enlightenment drew to a close, translation had gradually acquired an increasingly important role in the international circulation and transmission of scientific knowledge. Yet comparatively little attention has been paid to the translators responsible for making such accounts accessible in other languages, some of whom were women. In this article I explore how European women cast themselves as intellectually enquiring, knowledgeable and authoritative figures in their translations. Focusing specifically on the genre of scientific travel writing, I investigate the narrative strategies deployed by women translators to mark their involvement in the process of scientific knowledgemaking. These strategies ranged from rhetorical near-invisibility, driven by women's modest marginalization of their own public engagement in science to the active advertisement of themselves as intellectually curious consumers of scientific knowledge. A detailed study of Elizabeth Helme's translation of the French ornithologist Françoise le Vaillant's Voyage dans l'intérieur de l'Afrique [Voyage into the Interior of Africa] (1790) allows me to explore how her reworking of the original text for an Anglophone reading public enabled her to engage cautiously - or sometimes more openly - with questions regarding how scientific knowledge was constructed, for whom and with which aims in mind.
\end{abstract}

Outward Bound: Women Translators and Scientific Travel Writing, 1780-1800 Contents

Introduction

I. Gender, Science and Translation

II. Women as Scientific Translators in the Restoration and Enlightenment

III. 'Defrauded under the Plea of Female Delicacy': Helme's Translation of Vaillant's Voyage

Conclusions

\section{Introduction}


In 1790, the account by the French explorer and ornithologist François le Vaillant (1753-1824) of his travels to the southern parts of Africa, the Voyage dans l'intérieur de l'Afrique, par le Cap de BonneEspérance [Voyage into the Interior of Africa, via the Cape of Good Hope] appeared with the publisher Leroy in Paris. It was by no means the first European account to describe the people of the Cape of Good Hope - it was preceded by William ten Rhyne's Schediasma de Promontorio Bonae Spei (1686) [An Account of the Cape of Good Hope and the Hottentotes, the Natives of that Country (tr. 1704), Charles Rollin's Histoire moderne des Africains [Modern History of the Africans] (1769) and Peter Kolbe's Caput Bonae Spei Hodiernum, das ist vollständige Beschreibung des Afrikanischen Vorgebürges der Guten Hoffnung (1719) [The Present State of the Cape of Good Hope and the Hottentots (tr. 1731)] - but it was one of the most popular and influential European travelogues on Africa to appear before the start of the nineteenth century. It gave detailed descriptions of some of the 2000 specimens of exotic birds, mammals, insects, plants and Hottentot artefacts which Vaillant had collected on his journey between 1780 and 1785, many of which were hitherto unknown to Western science. Vaillant, the 'founder of African ornithology', ${ }^{1}$ therefore travelled less to accomplish what Mary Louise Pratt has suggested underpinned some forms of scientific exploration, namely territorial surveillance and administrative control, and more to extend the boundaries of scientific knowledge. ${ }^{2}$

Vaillant's account owed its success not only to his light and informal writing style, but also to his genuine interest in portraying the natives of Africa with a dignity that owed much to the philosophy of Rousseau. The Voyage also described his romantic liaison with the fair 'Narina', a Hottentot woman from the Gonaqua tribe and more generally expressed his evident admiration for Hottentot women in both words and pictures. His account included plates of 'A Hottentot woman' which showed her naked and with elongated genitalia - an image which caused huge scandal. It was either suppressed from later editions or reworked to present her in a less seductive position and to include a modest drape and an apron. Given that Vaillant's account was so influential, it comes as no surprise that in 1790, the same year of its publication in Paris, two rival translations of Vaillant's African travels appeared in Britain. The first of these was an anonymous translation, most likely by a man, which appeared with Robinson in London. The other translation, by contrast, was the work of a much more visible translator, and one who was clearly a woman, namely the popular novelist Elizabeth Helme. Her lightly abridged rendering of the original appeared with William Lane, the charismatic founder of the Minerva Press, which during the 1790s published a good third of all the novels produced in the capital, including the work of many women novelists. ${ }^{3}$

The British press was swift not only to register the appearance of Vaillant's account in its English renderings but also to compare and contrast these rival translations. While the critic in The

\footnotetext{
${ }^{1}$ L. C. Rookmaker, François Levaillant and the Birds of Africa (Houghton, 2004), 14.

${ }^{2}$ Mary Louise Pratt, Imperial Eyes: Travel Writing and Transculturation (London, 1992), 38.

${ }^{3}$ Stephen Behrendt, 'Publishing and the Provinces in Romantic-Era Britain', in The Cambridge Companion to British Romanticism, edited by Stuart Curran, 2nd ed. (Cambridge, 2010), 153-68 (162).
} 
European Magazine and London Review generously observed 'their respective merits appear to rise and fall so alternately in the progress of the narrative, that we are utterly at a loss to decide in whose favour the scale preponderates', the writer for The English Review was less magnanimous. ${ }^{4}$ In Lane's edition some ornithological terminology was completely wide of the mark: the 'canne petière' was not a 'duck' but a 'French field duck', 'a bird as different from the common duck as the common duck is from a partridge', the critic sourly noted..$^{5}$ The Critical Review, or Annals of Literature likewise considered the translation for Robinson 'more exact and close', but favoured Helme's translation for Lane as 'more free and elegant', noting that those 'who wish for a pleasing agreeable narrative will consequently peruse the latter', while 'the philosopher and physician, who wish for more scientific information' would prefer the former. ${ }^{6}$ But it was the critic in the Monthly Review who was most scathing of Helme's translation: 'The public have been so long disabused with misinterpretations of the natives of this obscure extremity of Africa, that every remark of an intelligent traveller becomes interesting: we are therefore sorry to find the latter of these translations was undertaken by a female pen, the dedication to the Duke of Montagu being signed Elizabeth Helme'. ${ }^{7}$ Indeed, he continued, 'The natural historian knows no indecency in his researches, whatever may be the object; when, therefore, $[. .$.$] a lady professes to give a translation of such a work, he will naturally be sorry to find$ himself defrauded under the plea of female delicacy' ${ }^{8}$

As I explore how and why Helme 'defrauded' the British reader 'under the plea of female delicacy', I examine a number of tensions at work in her translation. Helme played an essential role in mobilising both Vaillant's Voyage, by translating it for a different language group and culture, and her own readership, by sending them 'outward bound' into new worlds and cultures. Yet Helme was herself outwardly restricted, 'bound', by what she could viably do with the source text. Scholars of Translation Studies have explored a number of different ways in which gender is brought to bear on issues of translation. As Sherry Simon has noted, it is impossible to think of women and translation without focusing on the notion of agency, which in their case 'cannot be understood as that of a free

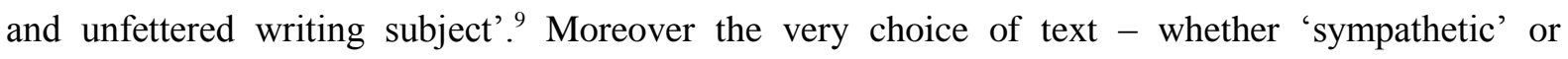
'antagonistic' to the interests and self-positioning of the translator - says much about the translator's readiness to engage with writing that stands in ideological, cultural or social opposition to herself. ${ }^{10}$ How and why a woman translator such as Helme became involved in working with a text as seemingly 'antagonistic' to women's propriety as Vaillant's account of the Cape is therefore intriguing, as are the means by which she made her presence felt in the text. Barbara Godard speaks of

\footnotetext{
${ }^{4}$ Anon., The London Review, October 1790, 285-87 (285).

5 Anon., The English Review, September 1790, 254-60 (260).

${ }^{6}$ Anon., The Critical Review, or, Annals of Literature, 1790, 34-45 (45).

${ }^{7}$ Anon., Monthly Review; Or Literary Journal, N.S. 3 (1790), 28-29 (28).

${ }^{8}$ Anon (note 6), 28.

${ }^{9}$ Sherry Simon, Gender in Translation: Cultural Identity and the Politics of Transmission (London/New York, 1996), 29.

${ }^{10}$ S. Simon (note 8$), 30$.
} 
'womanhandling' the text as a means by which female translators write their way into the text, a poetics of identity which might be called 'transformance' (transformation and performance), to signal critical difference, flaunt their manipulation of the text and replace the modest self-effacing translator by one who is highly visible. ${ }^{11}$ As I explore how Helme reworked Vaillant's account for a British audience, I examine how the activity of translation, often deemed derivative and unoriginal, offered women surprising possibilities to engage in the transmission of scientific ideas and, ultimately, the shaping of scientific knowledge.

This article seeks to trace the contribution made by women translators to the genre of scientific travel writing in the late Enlightenment. In this period, non-fictional travel literature enjoyed unprecedented levels of interest as books circulated, through translation, to ever wider audiences. This meant that figures such as James Cook and Joseph Banks, Georg and Reinhold Forster, Louis-Antoine de Bougainville and Jean-François de Lapérouse had literally become household names by the end of the eighteenth century. Translation, an important vehicle for such swift diffusion, fostered what has been termed by Fania Oz-Salzberger a 'multilingual modernity', in which the audience of readers interested in travel writing no longer belonged to a 'Republic of Letters' but were members of a much wider audience who comprised a 'Democracy of Letters'. ${ }^{12}$ In this article, I begin by considering the relationship between gender and scientific translation, before tracing in a second section the positions that women had already established in scientific authorship and translation by the time that Helme set to work on Vaillant's Voyage. In then go on to compare the two English translations with their French source text, and analyse the differences, exploring the extent to which they derive from the discursive and rhetorical difficulties that Vaillant's text posed to a translator who made no secret of her gender.

\section{Gender, Science and Translation}

As Scott Montgomery has demonstrated in his authoritative work Science in Translation: Movements of Knowledge through Cultures and Time (2000), knowledge has always 'been a mobile form of culture' and the transfer of learning critical to all societies in all historical periods. ${ }^{13}$ Those who facilitate the movement of knowledge are, Montgomery emphasises, influential people to whom various powers have been accorded, 'in the case of science, powers of imagination and practice with regard to the material world and uses of it' ${ }^{14}$ It has long been recognised, implicitly, by those working in the history of science that women played an invaluable, yet often invisible role as practitioners, amanuenses, educators and writers of elementary works on science. Patricia Phillips' seminal monograph The Scientific Lady: A Social History of Women's Scientific Interests 1520 - 1918 (1990)

\footnotetext{
${ }^{11}$ Barbara Godard, 'Theorising Feminist Discourse/Translation', in Translation, History and Culture, edited by Susan Bassnett and André Lefevere (London/New York, 1990), 87-96 (90).

${ }^{12}$ Fania Oz-Salzberger, 'The Enlightenment in Translation: Regional and European Aspects', European Review of History - Revue européenne d'Histoire, 13.3 (2006), 385-409.

${ }^{13}$ Scott L. Montgomery, Science in Translation: Movements of Knowledge through Cultures and Time (Chicago, 2000), 2.

${ }^{14}$ S. L. Montgomery (note 12$), 2$.
} 
still offers one of the richest and most detailed surveys of women's fascination with scientific activities in Britain. It remains such an important work precisely for its recognition that the women in the period studied were 'content to indulge their curiosity at an elementary level', that their low levels of achievement were due to the limited progress that women could make in scientific learning, as much of their own modest expectations of their intellectual abilities and that rigid social strictures determined what it was acceptable or inappropriate for a woman to do. ${ }^{15}$

Cast in a rather different vein, Joy Harvey and Marilyn Ogilvie's immensely comprehensive edited volume on women's international investment in scientific knowledge, the Biographical Dictionary of Women in Science: Pioneering Lives from Ancient Times to the Mid-Twentieth Century (2000), boasts much wider international coverage, including Asian, Latin American and Turkish women, as well as those from western Europe, America and Canada. The editors do, however, share Phillips' notion that what constitutes a 'contribution' to science could range from the small-scale to the ground-breaking. This dictionary therefore places the spotlight on those women translators of scientific material who are now relatively well known - such as Aphra Behn (1640-89), Mary Somerville (1780-1872), Clémence Royer (1830-1902) or Geneviève-Charlotte Arconville (17201805) - as well as more 'invisible' women like Giuseppa Eleonora Barbapiccola (fl. 1731), Mariia Bokova-Sechenova (1839-1929) or even Emma Darwin (1808-96), whose activities as translators have previously been overlooked. Collections such as Jean Delisle's Portraits de traductrices (2002) are particularly helpful in offering a balanced contextualisation of women's involvement in translation, scientific or otherwise, which neither sees them necessarily as 'trailblazers' or 'pioneers' nor necessarily suggests that their way of translating a given text was radically different from that of their male counterparts. ${ }^{16}$

From a history of science perspective important steps have therefore been made towards investigating the role played by women as translators of science. Scholars in translation studies have, however, been remarkably reluctant to examine the role women have performed as translators of nonfiction, preferring to focus their attentions on the activities in the area of fiction - principally poetry and prose - working on the premise that these genres were perceived as most 'acceptable' and therefore most empowering for women. I would argue that it is precisely where women ventured into less 'acceptable' terrain that the most interesting questions can be asked about gender and power. Recent publications on women, translation and science, such as Judith Johnston's 2013 volume, Victorian Women and the Economies of Travel, Translation and Culture, 1830-1870, have made useful inroads into analysing how women translated travel literature, and it is in the context of their engagement with this genre, which was already flourishing in the Enlightenment, that I analyse the contribution made by Helme.

\footnotetext{
${ }^{15}$ See Patricia Phillips, The Scientific Lady: A Social History of Women's Scientific Interests 1520-1918 (New York, 1990), xii.

${ }^{16}$ Jean Delisle, 'Présentation', in Portraits de traductrices, edited by Jean Delisle (Ottawa, 2002), 1-11.
} 
Translation has also long been gendered as an activity that properly falls within the preserve of male, rather than female, activities. The sexualisation of translation appears most memorably in the adage, coined in the seventeenth century, of translations being 'belles infidèles': like women, the saying went, a translation could either be beautiful or faithful, but not both. Translation therefore captured what Lori Chamberlain has described as 'a cultural complicity between the issues of fidelity in translation and in marriage', with faithfulness seen as a contract between the translation (inscribed as feminine) and the original (cast as masculine), which allows all the obvious power dynamics to be brought into play. ${ }^{17}$ To see women as producers of translations that were either elegant or accurate but not both was obviously immensely detrimental to their role in the international circulation of scientific writing, not least in the late eighteenth and early nineteenth century, when scientists set great store by the readability of their prose as much as the intellectual precision of the findings they conveyed. While, as we shall see, women generally produced highly accurate renderings of the texts they translated so assiduously - even to the point of correcting errors of calculation - their work was clearly considered to pose a threat to the established modes by which scientific knowledge was produced. But if translation was potentially a subversive activity, then it could equally be deployed by women to counter the prevailing power dynamics and, in de Lotbinière-Harwood's rephrasing, to act as 're-belles et infidèles'. ${ }^{18}$

\section{Women as Scientific Translators in the Restoration and Enlightenment}

Helme's involvement in the circulation of scientific knowledge through translation was not unprecedented in Britain. Quite the contrary: the Restoration dramatist and novelist Aphra Behn (1640-89) had already exploited the potential of scientific translation not only to cast herself as an intellectually enquiring woman but also to demonstrate her virtuosity as a translator. Indeed she prefaced her English rendering of Bernard de Fontenelle's Entretiens sur la pluralité des mondes (1686), which appeared as A Discovery of New Worlds in 1688, with her own essay on translated prose. In the translation's opening dedication to the Earl of Drumlangrig and his son, Behn had adopted a cautious, deferential approach:

If it is not done with that exactness it merits, I hope your Lordship will pardon it in a Woman, who is not supposed to be well versed in the Terms of Philosophy, being but a new beginner in that Science [...] and if it finds acceptance with your

\footnotetext{
${ }^{17}$ Lori Chamberlain, 'Gender and the Metaphorics of Translation', in Rethinking Translation: Discourse, Subjectivity, Ideology, edited by Lawrence Venuti (London/New York, 1992), 57-74.

${ }_{18}$ Susanne de Lotbinière-Harwood, Re-belle et infidèle. La traduction comme pratique de réécriture au feminine/The Body Bilingual: Translation as a Re-Writing in the Feminine (Montreal, 1991), 98-99.
} 
Lordship, I am already so much a Philosopher, as to despise what the World says of it ${ }^{19}$

But in her preface, she was vicious in her criticism of the power differential at work in Fontenelle's Entretiens, whereby a male natural philosopher taught his altogether rather simple female charge the basics of astronomy:

The Design of the Author is to treat of this part a Natural Philosophy in a more familiar Way than any other hath done, and to make every body [sic] understand him: For this End he introduceth a Woman of Quality as one of the Speakers in these five Discourses, whom he feigns never to have heard of any such thing as Philosophy before. [...] And for his Lady Marquiese, he makes her say a great many very silly things, tho' sometimes she makes Observations so learned, that the greatest Philosophers in Europe could make no better. ${ }^{20}$

Behn was therefore greatly troubled by Fontenelle's narrative treatment of the Marchioness, not least his stereotypical assumption that women were not able to cultivate their own minds and were intellectually inferior. Despite working in an age in which the Baconian scientific paradigms of empiricism, observation and experimentation prevailed, women were still metaphorically equated with nature, and man with the mind. Women's involvement in the construction of scientific knowledge therefore pressed at the boundaries of what constituted female propriety. As Mirella Agorni rightly points out, Behn's translation paradoxically offered her a better opportunity to articulate women's interest in science than one hundred years later. ${ }^{21}$ Elizabeth Plunkett nee Gunning's re-translation of Fontenelle's work for a nineteenth-century audience as the Conversations on the Plurality of Worlds (1803) was edited by the French astronomer Jérôme de Lalande. His editorial control over the text appears to have greatly limited any leeway its female translator might have sought for intellectual visibility. Elizabeth Carter was similarly 'silent' in her English rendering of Francesco Algarotti's Il Newtonianismo per le dame: ovvero Dialoghi sopra la luce e il colore (1737), translated as Sir Isaac Newton's Philosophy Explained for the Use of Ladies (1739): the name of the translator did not appear on the frontispiece, and Carter did not append any preface.

In terms of subject matter, the work of the German translator Dorothea Margarete ('Meta') Forkel (1765-1853) comes closest to Helme's translation of Vaillant for William Lane in 1790. Forkel, daughter of a professor at the University of Göttingen, had taken up translation in the 1780s

\footnotetext{
${ }^{19}$ Aphra Behn, Works: Volume 4 - Seneca Unmasqued and Other Prose Translations, edited by Janet Todd (London, 1993), 72.

${ }^{20}$ A. Behn (note 18), 77.

${ }^{21}$ Mirella Agorni, 'The Voice of the 'Translatress': From Aphra Behn to Elizabeth Carter', The Yearbook of English Studies, 28 (1998), 181-95 (182).
} 
and begun to work for the renowned scientific traveller Georg Forster, whose own prodigious activities were fuelled as much by intellectual curiosity about the latest accounts of voyages as a need to affirm his intellectual standing and to raise urgently needed money. ${ }^{22}$ Living in a university town with contacts in a variety of disciplines, Forkel was well placed to assist Forster in his translation work. As Monika Siegen reminds us, translation was not an unusual occupation amongst academics (and their immediate family), since the economic position of university staff was poor and competition between German booksellers for new works was fierce. ${ }^{23}$ It is only Forster's correspondence and knowledge of his biography (particularly his absences from Göttingen) that enables us to elicit that it was Forkel who translated, for example, the Memoirs and Travels of Mauritius Augustus Count de Benyowsky (1790) into German, doubtless working to a tight time schedule, given that this work promised to be immensely popular and therefore lucrative. In fact two other translations appeared within the space of one year. The eighteenth-century reader would, however, simply have registered that the preface to the German translation was by Georg Forster and the footnotes by his father, Johann Reinhold: while Meta was therefore strongly present in the text through her translation, it tended to be the male voices in the paratextual additions that were heard more clearly. ${ }^{24}$ Geneviève Roche's description of the conditions under which Meta was working in terms of an 'Übersetzungsfabrik' [translation factory] neatly captures the anonymity, time pressure and poor financial reward to which many translators subjected themselves as they used translation less to carve out a career and reputation for themselves than quite simply to earn a living. ${ }^{25}$

Forkel's case of translatorial 'invisibility' casts in a rather dark light recognition of women's contributions to non-fictional translation. Yet by the turn of the century, women were becoming more prominent figures in other genres located at the boundaries between literature and science. The translation of the Swiss botanist Albrecht von Haller's Alpine journey in the Poems of Baron Haller (1794) by one 'Mrs Howorth', self-proclaimed friend of the renowned botanist Sir James Edward Smith, is a compelling example of the ways in which women used translation to affirm their position within informal knowledge networks and to give themselves a public voice. ${ }^{26}$ Howorth's translation constituted an updating of Haller's work to embrace the Linnaean system of botanical classification and largely dispensed with the lengthy footnoting that had given Haller's work a strong scientific feel. Even if 'Mrs Howorth' stopped short of putting her first name to her translation (or perhaps her publisher advised her against such overt self-promotion), she was clearly a 'presence' in the

\footnotetext{
${ }^{22}$ The most authoritative study of Meta Forkel to date remains Monika Siegen's PhD thesis from the University of Darmstadt, Ich hatte einen Hang zur Schwärmerey .... Das Leben der Schriftstellerin und Übersetzerin Meta Forkel-Liebeskind im Spiegel ihrer Zeit, http://d-nb.info/1001530438/34 (accessed 02.12.2013).

${ }^{23} \mathrm{M}$. Siegen (note 21), 92.

${ }^{24} \mathrm{M}$. Siegen (note 21), 95.

${ }^{25}$ Geneviève Roche, 'Völlig nach Fabrikenart': Handwerk und Kunst der Übersetzung bei Georg Forster', in Weltbürger - Europäer - Deutscher - Franke, Georg Forster zum 200. Todestag, edited by Rolf Reichardt and Geneviève Roche (Mainz, 1994), 101-19.

${ }^{26}$ See Alison E. Martin, 'Natural Effusions': Mrs J. Howorth's English Translation of Albrecht von Haller's Die Alpen', Translation Studies, 5.1 (2012), 17-32.
} 
translation that more generally marked women's involvement in the rapidly developing science of botany. The rendering into English of Jacques De Lille's Les Jardins, ou l'art d'embellir (1789/1801) by the writer Maria Henrietta Montolieu (b. 1765) as The Gardens. A Poem (1798) with 'a considerable variety of entertaining notes by the translator' similarly indicates that women's public involvement in botanical poetry was deemed legitimate and unproblematic. ${ }^{27}$ Given that Montolieu would go on to establish a reputation as an author of botanical poetry - key works attributed to her are The Enchanted Plants. Fables in Verse (1800) and The Festival of the Rose (1802) - then translation clearly offered her a creative springboard into literary writing that enabled her to consolidate her position as a woman in the sphere of literary production. Certainly botany was one area in which British women were beginning to consolidate their position as translators and authors at the end of the eighteenth century - Maria Jacson's Botanical Dialogues between Hortensia and Her Four Children (1797), Charlotte Murray's The British Garden (1799) and Priscilla Wakefield's Introduction to Botany in a Series of Familiar Letters (1796) all appeared in the same decade as Helme's translation of Vaillant's Voyage. Entomology, chemistry and geology were other scientific fields in which women had also already become interested. Helme's involvement with ornithology seems to be an example of a very early engagement with women in a subject that was only taken up more energetically in the nineteenth century by women such as Sarah Bowdich Lee.

By late-eighteenth-century standards, Helme's promotion of herself in her preface as the author of the translation was therefore not unusual, although women authors publishing with Lane at the end of the 1780s did use other strategies on the title-page or in the front matter that would have been deemed more modest. Some hid behind the anonymous 'By a Lady', such as the author of Edward and Sophia (1787), or cross-referenced a work with previous productions, so Anne Hughes' Henry and Isabella (1788) was presented as 'By the author of Caroline, or the Diversities of Nature'; others, such as 'Mrs Bonhote, of Bungay, Suffolk', author of The Parental Monitor (1788), gave their surname and indication of marital status but stopped short of giving their first name; a very few women, like Ann Hilditch, author of Rosa de Montmorien (1787), allowed their names to appear in full on the title-page. ${ }^{28}$ It is difficult to discern any particular strategy at the Minerva press for presenting or concealing the identity of female translators, since there are so few examples: Sophia Lee's rendering of Warbeck. A Pathetic Tale (1786) from the French of the writer and dramatist François-Thomas-Marie de Baculard d'Arnaud was only identified as 'by the author of The Recess', while Ann Radcliffe's Radzivil (1790) 'Translated from the Russ[ian] of the celebrated M. Wocklow' bears no immediate indication as to the identity of its translator.

\footnotetext{
${ }^{27}$ William Thomas Lowndes, The Bibliographer's Manual of English Literature Containing an Account of Rare and Useful Books, 2 vols (London, 1834), II, 567.

${ }^{28}$ See Appendix I in Dorothy Blakey, The Minerva Press, 1790-1820 (London, 1939 [1935]), particularly 14057.
} 
Admittedly women translators remain shadowy figures even well into the nineteenth century - as indeed do men working in less prestigious genres - and a certain amount of archival spadework is still required to ascertain which translators ensured that works appeared on the Anglophone book market. The ledgers of the publishers Longman and Co. reveal, for example, that one 'Miss Merivale' was the translator of Johann Jakob von Tschudi's Das Thierleben der Alpenwelt. Naturansichten und Thierzeichnungen aus dem schweizerischen Gebirge (1853), which appeared in English as the Sketches of Nature in the Alps (1856), and that Jane Percy Sinnett produced the English translation of Ida Pfeiffer's Zweite Weltreise (1856), for which Pfeiffer also held the copyright and ensured that her own translator did not upstage her. Nevertheless there were also women translators whose presence was overt in the travel accounts they put into English and who deliberately used translation as a means to present themselves as confident intellectuals in the public sphere. Anne Plumptre, whose translation of Hinrich Lichtenstein's Reisen im südlichen Afrika; in den Jahren 1803, 1804, 1805 und 1806 (1812) Glenn Hooper suggests 'reveals an affinity for a more scientifically based model' of travel writing, made no efforts to be self-effacing or denigrating. ${ }^{29}$ Rather, as Susan Pickford shows in her detailed analysis of Plumptre's translation of François Pouqueville's Voyage en Morée, à Constantinople et en Albanie (1805), which appeared as the Travels in the Morea, Albania, and Other Parts of the Ottoman Empire with Henry Colburn in 1813, she employed a confident authorial voice that also suggested a high degree of agency in the translation. ${ }^{30}$ Indeed, as Pickford rightly argues, the repeated referral to Plumptre as translator in the various epitexts (notably reviews) which her translation generated, confirms that she achieved her desired visibility. ${ }^{31}$

\section{III. 'Defrauded under the Plea of Female Delicacy': Helme's Translation of Vaillant's Voyage}

Despite being one of the most popular British novelists at the end of the eighteenth century, Elizabeth Helme's life remains difficult to reconstruct. Her husband William, with whom she had five children, was a schoolmaster at Brentford, near London, and built up a reputation as a writer of educational books. Helme appears to have begun publishing in the 1780s to supplement the family's meagre income and produced at least ten novels that are identifiable as her work, together with certainly two translations and a few didactic works for young people. Among Helme's publications, described by her daughters in a request to the Royal Literary Fund for money after her death as 'invariably of a moral tendency', are Louisa: Or the Cottage on the Moor (1787), which continued to be reprinted

\footnotetext{
${ }^{29}$ Glenn Hooper, 'Anne Plumptre: An Independent Traveller', in Gender Perspectives in Nineteenth-Century Ireland: Public and Private Spheres, edited by Margaret Kelleher and James H. Murphy (Dublin, 1997), 129-39 (132).

${ }^{30}$ Susan Pickford, 'Writing with "manly vigour": Translatorial Agency in Two Early Nineteenth-Century English Translations of François Pouqueville's Voyage en Morée, à Constantinople et en Albanie (1805)', in Travel Narratives in Translation, 1750-1830: Nationalism, Ideology, Gender, edited by Alison E. Martin and Susan Pickford (London, 2012), 197-217 (209).

${ }^{31}$ S. Pickford (note 30), 211.
} 
until the end of the nineteenth century, and The Farmer of Inglewood Forest (1796). ${ }^{32}$ Clichéd in plot and character, her work nevertheless earned her critical acclaim, The Farmer of Inglewood Forest being described as a work that could be read 'without fear of exciting evil passions, or inculcating any pernicious principles whatever'. ${ }^{33}$ Certainly Helme's ongoing interest in problems of class, race, and social justice - doubtless encouraged by her work as a headmistress towards the end of her life would have drawn a wide audience. As a translator, she was more prodigious than we might imagine. Helme indicated to the Royal Literary Fund that she had 'translated sixteen volumes for different booksellers without my name', implying that she was involved in more than just Vaillant's Travels, Johann Heinrich Campe's play Cortez: Or, the Discovery of Mexico (1799) and his Columbus: Or, the Discovery of America, as Related By a Father to His Child (1811), which are the works now directly attributed to her. She was clearly interested in the pedagogical potential of travel writing, given that she wrote the Instructive Rambles in London and Adjacent Villages: Designed to Amuse the Mind, and Improve the Understanding of Youth (1798). This, together with the popularity that Vaillant's African account seemed to promise, may well have attracted her to the Voyage. Just as Helme's career as a novelist was motivated by financial concerns, so too may have been her translation work. 'For seventeen years I have written for the press, and by that means supported myself respectably, and materially assisted a large family', she wrote in a request for financial relief to the Royal Literary Fund in 20th October 1803, as poverty began to gnaw. ${ }^{34}$

The Robinson translator, whose identity has yet to be identified,$^{35}$ essentially provided a scholarly translation of the original which included the original 'Author's Preface', added footnotes to explain scientific terminology, offered a full rendering of the text of Vaillant's account and even included the 'shocking' image of the Hottentot woman uncovered. Since, as we have discussed above, many anonymous translators were female and such scholarly translation was well within the grasp of women, it is not impossible that this was the work of a female translator. However, this translator took great pains to ensure that his or her identity was not made known to the reading public (and therefore also reviewers) in the translation. Given how many agents are involved in the translation process, it is worth remembering that the decision not to exclude the naked Hottentot could, in any case, have been taken by a male editor, with a view to offering a comprehensive rendering of the original that would

\footnotetext{
${ }^{32}$ For details of Helme's biography see http://extra.shu.ac.uk/corvey/corinne/1Helme/BioHelme.html (accessed 26.11.2013), http://orlando.cambridge.org/public/svPeople?person_id=helmel (accessed 26.11.2013), and http://www2.warwick.ac.uk/fac/arts/emforum/projects/brieflives/elizabeth_helme/ (accessed 26.11.2013).

33 Anon., The Critical Review, or, Annals of Literature, February 1797, 227.

${ }^{34}$ Quoted in Fiona Harlow's 'Author Biography: Elizabeth Helme', http://www.chawton.org/library/research/helme_louisa_biog.pdf (accessed 30 March 2012).

35 Material relating to the publisher George Robinson is held in the archives of Manchester Public Library, currently closed for refurbishment. G. E. Bentley junior's detailed article 'Copyright Documents in the George Robinson Archive: William Godwin and Others, 1713-1820', Studies in Bibliography, 35 (1982), 67-110, suggests these archives could hold valuable information about the translators who worked for Robinson, including the individual who provided the competing translation of Vaillant's Travels.
} 
be a valuable selling point against competing, abridged editions being prepared for the English market.

Helme's English rendering of Vaillant's account was cast in quite a different vein, with examples of translatorial visibility and agency present from the very outset. It included a dedication from Helme to 'His Grace the Duke of Montagu', a translator's preface (substituted for the author's preface), additional chapter headings which subdivided the narrative into more easily digestible portions, fewer footnote references, so that would the translation would have less of an overly scientific, 'masculine' air and, finally, it omitted sections that included subject matter inappropriate for female readers, so, mentions of genitalia or reproduction. The title-page is a good place to start in understanding how Helme repackaged Vaillant's account to make it more attractive to a wider audience that could comfortably include women. The addition of the subtitle 'Including Many Interesting Anecdotes, with Elegant Plates' already suggested that it was not to be stuffed with dry, scientific fact. The reference to anecdotes, which ally the personal and the private (traditionally 'feminine' literary domains) with public concerns, suggested that it would be an entertaining piece. Furthermore the 'elegant' plates implicitly signalled the work's suitability also for a female readership, suggesting it would not transgress the boundaries of female modesty. This was indeed the case, since the Hottentot woman was suitably covered up. The dedication to George Montagu, First Duke of Montagu (1719-90), who had been invested as a Fellow of the Royal Society in 1749, suggested - much in the same way as Behn's translation of Fontenelle had done - that this work (and its author) enjoyed the patronage, the support and the protection of a male figure. Helme also used her dedication to sustain a discourse of modesty. Rather than suggesting that she had translated Vaillant in the pursuit of her own intellectual or financial interests, her work was presented as hoping to 'succeed in amusing an hour of your GRACE's leisure' and appealing to his 'fondness for science, and love of humanity.${ }^{36}$ While Helme's name did not appear on the title-page, she was certainly 'visible' by the time the reader had leafed to the 'Translator's Preface': here she admitted to 'curtailing a few repetitions' and noted, 'I have likewise softened (if I may be allowed the expression) a few passages that possibly might be accounted mere effusions of fancy and vivacity in a french [sic] author, but which will ill accord with the delicacy of a female translator, or indeed with the temper and genius of English readers' ${ }^{37}$ Using both gendered and national differences to justify her omissions, Helme therefore sought to deflect potential criticism away from her potential unsuitability, as a woman, to translate Vaillant.

Helme's organisation of Vaillant's material into separate chapters not only broke the information down into portions that could more easily be read at one sitting. They enhanced the feel that this was more of a 'narrative' by giving it greater linearity and cohesion. But she not only

\footnotetext{
${ }^{36}$ François le Vaillant, Travels from the Cape of Good-Hope, into the Interior Parts of Africa, Including Many Interesting Anecdotes, with Elegant Plates, 2 vols, trans. by Elizabeth Helme (London, 1790), I, vi-vii.

${ }^{37}$ F. Vaillant (note 36), I, ix-X.
} 
heightened the readability through strengthening the structure of the narrative: she also used parenthetic additions to make Vaillant's text more easily comprehensible. Thus when Vaillant described the weapons he took with him by saying 'je m'armai de la Sarbacane \& de l'Arc Indien', ${ }^{38}$ she put 'I therefore armed myself with a Sarbacane, (a tube to shoot with) and an Indian bow' ${ }^{39}$ The translator for Robinson, by contrast, footnoted his text to give it a more scholarly air, making of the same passage 'I armed myself with a tube*, and an Indian bow', adding in the footnote '*Sarbacane a kind of tube, through which small parts are blown with the mouth' ${ }^{40}$ Helme would routinely use parentheses to keep material in the main text, thereby aiming her translation at the general public, rather than presenting it as a more serious scientific account for specialists.

The translator for Robinson clearly possessed - and was prepared to vaunt - greater scientific knowledge. Thus in describing the marine life at Table Bay, Helme simply translated the original French literally:

Les Cachelots, espèce de Baleine que les Hollandois appellant Noord-Kaaper, abondent $\&$ jouent continuellement dans ce bassin. ${ }^{41}$

The Cachelots (a sort of whale, which the Dutch call noord-kaaper) are very numerous, and continually playing in this bay. ${ }^{42}$

Her counterpart for Robinson produced a more detailed translation with footnotes:

The cachelot*, a kind of whale which the Dutch call noord kaaper, is always found in great plenty sporting in this bason.

* The cachelot was generally known under the name of the spermaceti whale, till Mr. Pennant very properly made a distinction, by borrowing its name from the French. T. ${ }^{43}$

The translator of the Robinson edition was therefore not only au fait with the various species that Vaillant had mentioned, but could contextualise them within developments in travel writing, referring here to Pennant to show breadth of reading - a comment that also injected a certain patriotism into this translation by demonstrating British contributions to the advancement of science.

The style of the translation for Robinson is also markedly different from Helme's version at various points. Having reached the Gamtoos River in the Eastern Cape Province of South Africa after a particularly dangerous journey, and set up camp, Vaillant and his fellow travellers woke to the sound of birdsong:

\footnotetext{
${ }^{38}$ François Vaillant, Voyage dans l'intérieur de l'Afrique, par le Cap de Bonne-Espérance (Paris, 1790), I, xii.

${ }^{39}$ F. Vaillant (note 36), I, xvi.

${ }^{40}$ François Vaillant, Travels into the Interior Parts of Africa by the Way of the Cape of Good Hope; In the Years 1780, 81, 82, 83, 84 and 85, 2 vols, trans. anon (London, 1790), I, 6.

${ }^{41}$ F. Vaillant (note 38), I, 16.

${ }^{42} \mathrm{~F}$. Vaillant (note 36$), \mathrm{I}, 38$

${ }^{43}$ F. Vaillant (note 40), I, 45.
} 
De bon matin, je fus de nouveau réveillé par des ramages qui n'étoient pas moins de mon goût. C'étoient des oiseaux que je ne connoissois point, \& que je n'avois jamais entendus. Je les trouvai magnifiques. Je fus ébloui par le brilliant \& le changeant des Etourneaux-cuivrés, du Sucrier à gorge améthiste, du Couroucoucou, du Martin-chasseur, \& de beaucoup d'autres. Je vis aussi des especes que j'avois déja rencontrées. ${ }^{44}$

Helme offers a remarkably condensed version of this passage:

In the morning I was awakened by the warbling of birds, some of which were totally unknown to me. I found part of them very beautiful, the bright coppercoloured Starling, crested cuckow [sic], and the King Fisher, were among the number. ${ }^{45}$

The translator for Robinson produced quite a different text both in narrative approach and length:

Early in the morning I was again awakened by a warbling, which afforded me no less pleasure. It proceeded from birds which I did not know, and which I had never before heard. I found them most beautiful. I was dazzled by the brilliant and variable plumage of the copper-coloured starling, the amethyst-coloured throat of the certhia flaveola*, the courou-coucout, the king's-hunter, and of a great many others: I observed also several species which I had never before seen.

* In the original sucrier; called also by Brisson grimpereau; and by Sir Hans Sloan, in his Natural History of Jamaica, the black and yellow bird.

$\dagger$ Curucui, a Brasilian bird. Trogon Linn. T. ${ }^{46}$

It is striking how much more complex, colourful and detailed the Robinson translation is, suggesting that it would have attracted the interest of a broader non-specialist audience. There are greater attempts to appeal to the reader's imagination, perhaps inspired by the translator's own knowledge of the exotic birds being described, dazzling in their 'brilliant variable plumage', and a need to convey a sense of awe and wonder that actually leads to a mistranslation at the end of the quoted passage, adding a negative in 'which I had never seen before' that is not present in the original 'que $\mathrm{j}$ 'avois déjà rencontrées'. Yet scientific readers would not have been short-changed by the Robinson translation either - as indeed the writer for the Critical Review had noted. They would have found this translation to their liking, given its confident references to terms in the Linnaean system of classification and to related works such as Sir Hans Sloane's Natural History of Jamaica (1707-25). In this example in particular, the translator for Robinson clearly feels much more at ease with the ornithological terminology and more readily able to picture the birds being described.

\footnotetext{
${ }^{44}$ F. Vaillant (note 38), I, 174-75.

${ }^{45}$ F. Vaillant (note 36), I, 287.

${ }^{46}$ F. Vaillant (note 40), I, 259.
} 
On what kind of authority the translator for Robinson was able to make such statements does, however, remain unclear. And if Vaillant's work was indeed so ground-breaking, how could this translator have been so self-assured in offering translations of the names of birds hitherto unknown? Specialist guides such as William Swaison's Birds of Western Africa did not appear until 1837 and any previous writing on African birdlife was often incorporated into larger narratives such as the Living curiosities, to be seen in the Great-Room, over Exeter-Change, the finest assemblage in this kingdom. Consisting of two collections, one of capital and uncommon beasts, the other of curious and rare birds; selected from Asia. Africa and America (1790), which was more interested in registering wonder at exotic fauna than of categorising them scientifically. Whether Hans Sloane's Natural History of Jamaica was particularly relevant to a discussion of African ornithology is also debatable. While the translator for Robinson therefore quickly generated the air of being knowledgeable, it may be that the difficulties which Helme repeatedly registered at finding the correct ornithological term were in fact less an indication of her personal shortcomings and more an honest reflection on the state of ornithological knowledge in the period. She frequently left the French untranslated, so that she spoke of the 'Gobe Mouch' [sic], adding in brackets 'Fly Catcher', while the other translator was much less tentative about describing this species as the 'red long-tailed fly-catcher'. ${ }^{47}$ By not translating the French, Helme could be seen to be adopting a foreignising strategy that deliberately signalled the lack of an established vocabulary in English in this discipline and the need for British scientists to decide on names for species hitherto unknown.

If some British readers might have been disappointed by Helme's poor attempts to find an adequate translation for these particular terms, they might also have been concerned to discover that she had sometimes left out whole sentences altogether. In a passage on the mammary glands and milk of elephants, she abridged the text so that Vaillant declared the taste of elephant's milk to be:

...sweet, but of a disagreeable flavour, and flowed from eight small punctures; the others had two as usual. ${ }^{48}$

There her translation of this paragraph ends. In the translation for Robinson, a little more was included:

... this milk issued from eight small orifices, very perceptible and distinct. The rest had two dugs, placed generally under the breast, of the same form as those of women; and of such a size, that more than one lady of pleasure who has lost a little of her plumpness, might have envied this charm in my female elephants. ${ }^{49}$

\footnotetext{
${ }^{47}$ F. Vaillant (note 36), I,433; F. Vaillant (note 40), I, 387.

${ }^{48}$ F. Vaillant (note 36), I, 262.

${ }^{49}$ F. Vaillant (note 40), I, 237.
} 
While this reference to 'one lady of pleasure' adds a sexual soupçon to this English translation, no such allusions were present in the original French, which simply refers to a female coxcomb or pretentious woman -- 'une petite-maîtresse, que désole un peu trop d'embonpoint, eût envié ce charme à mes fémelles d'Eléphant' ${ }^{50}$ Nevertheless the juxtaposition of women and elephants was clearly taking things a little far for Helme.

Even more sober comments by Vaillant did not appear in Helme's rendering of the voyage. The most oblique reference to male nakedness was removed by Helme, so that in her translation of the account of the male Gonaquais she has:

When the heat is excessive, they take off all their covering but their jackals, which is a piece of skin of the animal so named, and hangs from their girdles. ${ }^{51}$

The Robinson translation had a little more to say on the matter:

When the weather is excessively hot, the men lay aside every part of their dress that is superfluous, and retain only what they name their jackals. This is a piece of the skin of the animal so called, with which they cover what nature bids them to conceal, and which is fastened to their girdle. This veil however, negligently arranged, may be considered as a useless appendage, as it is of very little service to their modesty. ${ }^{52}$

The reasons why this passage were omitted by Helme are not difficult to imagine. Critics' dismay at her translation not being comprehensive also seems rather exaggerated, given how little concrete information she cut out in the interests of making this translation appropriate to a wider audience, including women. Indeed one might even suggest that the criticism levelled by the Monthly Review at Helme's version essentially had less to do with her diplomatic abridgements and more with a sense of indignation at women meddling in matters for which they were considered, by some, to be wholly unsuitable.

Yet if the content of Vaillant's account seemed to limit Helme as a translator, it did acquaint her with material that she could use in her own creative writing, notably The Farmer of Inglewood Forest (1796), which also appeared with the publisher William Lane. I think it no coincidence that in this novel, which sets issues of guilt and divine forgiveness against the backdrop of remote British colonial landscapes, she used the Cape of Good Hope as a strikingly 'foreign' location to lend her exotic narrative distinctly Rousseauian qualities. The narrator's uncle is cast away on his return from India to England and plans with a few companions to explore his way to the Cape of Good Hope. The terrain is such that they must penetrate thick forests, cross rapid rivers, and climb almost perpendicular mountains. Interestingly they end up in a Dutch settlement:

\footnotetext{
${ }^{50}$ F. Vaillant (note 38$)$, I, 158.

${ }^{51}$ F. Vaillant (note 36$)$, II, 3.

${ }^{52}$ F. Vaillant (note 40), II, 3.
} 
where their appearance caused no small surprise, for my uncle, as well as his companions, were naked, the small remains of covering the natives had left them having been so long worn out, that they were grown perfectly familiarized to the omission, and their skins changed to the complexion of copper ${ }^{53}$

It is intriguing that Helme did not feel inhibited in her own prose about making her male characters explicitly naked. But here she was using the body as a political object, and by making the Europeans acquire the skin tone of the Hottentots and essentially adopt their way of life, she was making a covert political statement: Vaillant's account had lauded the equality of marriage in Hottentot society and the respect that the sexes had for each other. Given that many of Helme's novels also focus on 'personal morality and its relationship with class and wealth ${ }^{54}$ it may be that by making her European characters 'go native', she was also reflecting upon the greater sense of moral worth to be found in such 'savage' cultures than in her own.

\section{Conclusions}

Helme's translation of Vaillant's Voyage highlighted a number of obstacles but also opportunities to be found in the translation of scientific travel writing by women. That this text was both an enabling and a challenging piece was clear from Helme's preface. Her translation of Vaillant's account allowed her to develop her public profile as a cultured, multilingual woman, while also emphasising just how difficult it was - given the specific terminology and background knowledge required - for a female translator to enter upon the terrain of male scientific travel writing. While Helme doubtless lacked the prior knowledge required to give a confident (and accurate) translation of the ornithological details in this travelogue, the differences between her rendering and that by the translator for Robinson turn upon another issue altogether: the audience for whom they felt they were writing. Helme's translation obviously sought to be more inclusive and more 'popularising' by avoiding excessive scientific detail and making of Vaillant's text what the author in the Critical Review rightly identified as 'a pleasing agreeable narrative'. The translator for Robinson adopted a different tack: by making better use of the marginal spaces on the page, it was possible to produce a translation that appealed as much to a general public reading the main body of text as to the scientific lay person who could delve into the footnotes for further detail and greater contextualisation of Vaillant's account within the wider body of Anglophone writing on natural history. For male critics seeking an intellectually weighty approach to the translation - both textual and cultural - of Vaillant's Voyage, it was clear that the edition published by Robinson would court more approval. Contemporary criticism notwithstanding, Helme's

\footnotetext{
${ }^{53}$ Elizabeth Helme, The Farmer of Inglewood Forest (London, 1841), 75.

${ }^{54}$ Virginia Blain, Patricia Clements and Isobel Grundy (eds.), The Feminist Companion to Literature in English: Women Writers from the Middle Ages to the Present (London, 1990), 509.
} 
translation clearly made a successful bid to render this text and its subject matter more palatable for a wider British audience that also included women. I would be cautious, though, about considering that she 'hijacked' the text for any overtly proto-feminist ends. Rather, I would suggest that translation offered her entry into foreign territory, which as an 'exotic' figure herself in the field of male scientific travel, she could more comfortably use for her own ends in the arguably less fettered world of fiction.

\section{Acknowledgements}

The author wishes to thank her anonymous reviewer for swift and insightful feedback on an earlier draft of this article. 